\title{
The Position and Authority of the State Audit Board in the Indonesian Constitutional Structure
}

\author{
M. Afif Hasbullah \\ Universitas Islam Darul Ulum Lamongan, Indonesia \\ Email: afif@unisda.ac.id
}

\begin{abstract}
This study aims to analyze the position and authority of the Supreme Audit Agency's audit in the Indonesian state administration structure. The research method used is the juridical-normative concept. This research uses statutory law materials and legal journals that have the subject of State Finance Law. This research was also conducted by analyzing the primary legal material, namely by examining theories, concepts, legal principles and legislation related to State Finance Law. Based on the study and analysis of legal sources, it can be concluded that the position of the Supreme Audit Agency of the Republic of Indonesia in the state administration system is a state institution whose authority is granted by the 1945 Constitution of the Republic of Indonesia (constitutionally entrusted power) so that it can be called the main state organ or the primary state agency. The State Audit Board has the authority to carry out audits of state and regional financial management as mandated in Article 23E of the 1945 Constitution of the Republic of Indonesia and Law Number 15 of 2006 concerning the State Audit Board.
\end{abstract}

Keywords: Position, Authority, Supreme Audit Agency.

\section{A. INTRODUCTION}

From the point of view of the 1945 Constitution, which is the written constitution of the State of Indonesia from an economic perspective, it shows that the Indonesian state adheres to the understanding of the welfare state, which is embodied by the Government (Suwanda, 2015). The government is a public entity that must be accountable for its performance in regular financial reports. In addition, the government is also obliged to carry out financial management in an orderly, obedient, economical, effective, efficient and transparent manner (Setyawati, 2016). Examination of the government's performance on the control of state finances is carried out to identify a problem that exists in the management of the activities of the entity being examined by assessing several aspects, including the economic part, or the effectiveness of programs/activities to avoid wasting state finances or government programs that do not reach the target-desired (Kusumo, 2018). This performance check produces valuable information to improve the performance of a program, facilitates decision-making for those responsible for overseeing actions, and increases the program's accountability to the public (Hasiara \& Padliansyah, 2017).

The conception of the welfare state assumes that the state aims to provide welfare for all its people; this is marked by the inclusion of state intervention in 
populist-based economic activities. For example, the 1945 Constitution explicitly regulates state intervention in the economy; this regulation is regulated in Article 33 paragraphs (2) and (3). This provision explains how the state's contribution to the economy is in the form of "control rights" over water, earth, and the wealth they contain, as well as every branch of production that has fulfilled essential criteria for the state and controls the livelihoods of many people, to be used for welfare-the people at large. Therefore, performance checks must be monitored to minimize fraud that hinders the welfare of the people (Dharma et al., 2017).

Performance audits (performance audits) arise because of public dissatisfaction with financial audits, which only assess the fairness of financial statements. People want to know whether the state money that comes from the taxes they pay is appropriately managed. People want to get certainty whether state money is used to obtain resources effectively, used efficiently and can provide optimal results that bring benefits to them (Zulkarnain, 2014). The community also wants to know whether the implementation of activities by the government using public funds can provide more value for improving people's welfare.

In the current reform era, the Supreme Audit Agency has received constitutional support from the People's Consultative Assembly of the Republic of Indonesia in the 2002 annual session, which strengthened the position of the Supreme Audit Agency as an external audit institution in the field of state finances, namely the issuance of TAP MPR No. VI/MPR/2002, which among others reaffirmed the position of the Supreme Audit Agency as the only external auditing agency for state finances.

The Supreme Audit Agency has excellent authority to provide opinions on state financial management and accountability (Aminah et al., 2016). This examination of the control and responsibility of state finances is aimed at enforcing the law on irregularities in state finances. As a state of law, the audit of financial management must be guided by the sources of law that have been determined. Financial audits have legal authorities as contained in Article 23E, Article 23F, and Article 23G of the 1945 Constitution of the Republic of Indonesia.

Furthermore, in a scientific oration entitled 'The Urgency of Professionalism in Financial Management Through Financial Reporting Obligations' conducted by the chairman of the Supreme Audit Agency of the Republic of Indonesia, Prof. Dr. Moermahadi Soerja Djanegara, CA., CPA, is concerned about the potential for vacancies in his institution if the People's Consultative Council does not complete the selection process for prospective members. The slowness of the selection process by Commission XI of the People's Consultative Council is widely regarded as a procedural flaw. In addition, in the plenary meeting of the People's Consultative Council, the chairman of the Supreme Audit Agency revealed that his party had found 14,965 problems in the use of the State Budget. These problems include 1) 7,236 internal control system weakness problems; 2) 7,636 non-compliance with legislation; and 3) 93 problems related to ineffectiveness, inefficiency, and ineffectiveness. 
Of all these problems, 4,838 problems amounted to IDR 9.68 trillion and resulted in state losses of IDR 2.47 trillion caused by 3,162 issues. According to the Supreme Audit Agency's records, the potential loss is 502 problems worth IDR 1.31 trillion. The lack of receipts is 1,174 problems with a value of IDR 5.9 trillion; besides, 2,798 problems result in administrative irregularities. State financial losses occur due to negligence in using excessive budgets that are not following their primary functions and targets. State financial losses in the legal dimension of state administration have a clear definition as contained in Article 1 number 22 of the Law of the Republic of Indonesia Number 1 of 2004 concerning the State Treasury and Article 1 number 15 of the Law of the Republic of Indonesia Number 15 of 2006 concerning the Audit Board.

The state losses can be in the form of money, goods. Securities within the scope of State Finance as regulated in Law of the Republic of Indonesia number 17 of 2003 concerning state finances, Law of the Republic of Indonesia Number 15 of 2006 concerning the Supreme Audit Agency, and Law No. Law of the Republic of Indonesia Number 31 of 1999, Law of the Republic of Indonesia Number 20 of 2001, but narrowed it down with specifications in the form of tangible and definite numbers due to unlawful acts, either intentionally or negligently (Bintari, 2017).

State financial losses must be accurate and definite in amount proportional to the definition of state finances themselves, including state financial losses are waste in the form of: 1) Unlawful Acts (PMH) spending money for something that is not planned by the State/region, not based on analysis needs, and not budgeted; 2) Reduced regional rights, due to loss of income (which has been included as income or which is potential revenue); 4) Increased obligations (the criterion for determining this increased obligation is whether there is $\mathrm{PMH}$ or not) which is not budgeted for by individual officials, not for the interest of the state; 5) Payment in excess of the value that should be paid: a) payment for activities whose volume is less or does not meet specifications; b) payments for unfinished projects; c) payment for goods/services that exceed the market price; 6) Purchases with a high value with market prices or comparisons with the exact specifications, place, and year, then the price difference is a loss (not a waste) (Astuti \& Adrison, 2019). In addition to this, state financial losses in the dimension of state administrative law will also always refer to legality, which has the core of the authority to determine state financial losses so that it has legitimacy.

To supervise this, the government must perform oversight/audits of various State Budget money usage. Regional revenue and expenditure budgets and state assets segregated and employed by government agencies following State Administrative Law are actions that compare what is being done, done, or done with what is wanted, planned, or commanded (Adrison, 2019). The objective of supervision is to ascertain whether or not duties and work have been appropriately completed. In terms of calculating state financial losses, supervision can take the following forms: 1) Internal supervision by superiors to subordinates in a work environment; Inspectorate General, Provincial Inspectorate, and City Regency 
Inspectorate; Financial and Development Supervisory Agency; and 2) External supervision by the Supreme Audit Agency (Komalasari, 2016; Syafrina \& Prayogi).

The problem that now occurs in the Non-Departmental Government Institution (LPND) of the State Audit Board is related to the report's results on the calculation of state financial losses conducted by the State Audit Board. These problems arise when investigators are faced with cases of Corruption Crimes that require experts in calculating state financial losses (Julianti \& Pamungkas, 2019). One of the institutions capable of calculating state financial losses is the State Audit Board, so investigators often ask the Supreme Audit Agency to conduct an investigative audit to determine the amount of state financial losses. However, when the investigative audit report is used as evidence in the trial, the defendant is permanently excluded, accompanied by his attorney (Kusumawati \& Syamsuddin, 2018). This often happens because the Supreme Audit Agency is considered to have no authority in calculating state financial losses. In addition, the report on the results of the investigative audit conducted by the Supreme Audit Agency is also often a problem because the results of the investigative audit conducted by the State Audit Board at the request of the investigator are included in the meaning of a State Administrative Decree or vice versa. Therefore, it is necessary to review the duties and authorities of the Supreme Audit Agency in the constitutional structure of the Republic of Indonesia.

\section{B. METHOD}

The research method used is the juridical-normative concept. This research uses statutory law materials and legal journals that have the subject of State Finance Law. This research was also carried out by analyzing the primary legal material, namely by examining theories, concepts, legal principles and laws and regulations related to State Finance Law (Prohudono et al., 2018). The juridical-normative approach is also known as the library approach. The legal source analysis technique is then processed and analyzed using qualitative processing techniques. The presentation of the results is carried out in a descriptive-analytical manner to obtain conclusions from the problems that have been proposed.

\section{RESULT AND DISCUSSION}

\section{The Position of the Supreme Audit Agency in the Indonesian State System}

The position of the BPK in the constitutional system of the Republic of Indonesia when viewed from the authority granted directly by the 1945 Constitution of the Republic of Indonesia, this state institution is classified as a State Institution whose authority is granted by the 1945 Constitution of the Republic of Indonesia (constitutionally entrusted power). Sri Soemantri's opinion states that in the 1945 Constitution of the Republic of Indonesia, there are eight that can be referred to as state institutions. The eight consist of the Supreme Audit Agency, the House of Representatives, the Regional Representatives Council, the People's Consultative Assembly, the President and Vice President, the Supreme Court, the Constitutional 
Court, and the Judicial Commission. The opinion is based on the idea of the state institutional system in the 1945 Constitution of the Republic of Indonesia, which is divided into three fields/functions, namely 1) in the field of legislation; 2) related to supervision; and 3) related to the appointment of the supreme judge (Aswar, 2019).

Aswar (2019) also stated the 1945 Constitution of the Republic of Indonesia had adopted a system of the functional distribution of the authority of state institutions by stipulating certain functions needed to administer the state administration. These functions are: 1) the establishment and amendment of the fundamental law (executed by the MPR); 2) legislators (executed by the House of Representatives); 3) government implementation (run by the President and Vice President); 4) judicial administrators (implemented by the Supreme Court and the Constitutional Court); 5) other functions to improve the quality of governance to create good corporate governance (implemented by Judicial Commission, and other institutions of constitutional importance).

Judging from the position of the State Audit Board as the primary state organ in the sense that it is a state institution that is free and independent. The results of the state financial audit should be submitted to the House of Representatives, Regional Representatives Council, and Regional People's Representative Council because it will cause a conflict of interest. The location of the competition will arise if those examined are the House of Representatives, the Regional Representatives Council, and the Regional People's Representative Council itself. Whatever the results of the examination by the Supreme Audit Agency, the action will depend on the House of Representatives. In this regard, an effective mechanism is urgently needed so that the results of the audit from the Supreme Audit Agency on state finances are not in vain and on target.

It is necessary to reformulate the proper relationship between the House of Representatives, Regional Representatives Council, Regional People's Representative Council, and the Supreme Audit Agency to continue to carry out their functions as state institutions following the principle of checks and balances. The focus of Check and Balances itself, according to Black's Law Dictionary, means "arrangement of governmental powers whereby powers of one governmental branch check or balance those of other branches." balance the other branches. This is the principle of modern democracy and the rule of law. Furthermore, the understanding of checks and balances is in Berman's opinion, saying that: "checks and balances are the constitutional controls whereby separate branches of government have limiting powers over each other so that no branch will become supreme".

The checks and balances that appear in the 1945 Constitution of the Republic of Indonesia want to balance the branches of state power. The relationship is arranged so that there is no concentration of power in one chapter of state power. When viewed from the functions and objectives to be achieved, checks and balances will be able to create a democratic and clean government (Ruliana et al., 2017). This is because there is no main dominant power; all are balanced according to their 
respective authorities. However, this will mean the opposite if the state administration system, especially institutions, is not yet well established to regulate the pattern of relations related to the authority of each state institution.

\section{The Role and Authority of the Supreme Audit Agency of the Republic of Indonesia}

The Supreme Audit Agency is regulated in Article 23 E of the 1945 Constitution, which explains that the State Audit Board is an independent agency to examine state finances' management and responsibilities. The results of the audit by the Supreme Audit Agency are submitted to the representative institutions following their authority to be followed up. This provision confirms that the Supreme Audit Agency is an institution that has the power to conduct audits of state financial management (Idrus et al., 2018).

This authority is also referred to as formal power, which comes from the power granted by law or executive management. Within the head, there are powers (rechtbe voegdheden). Authority is an environment of public legal action; the scope of government authority includes the authority to make government decisions (bestuur) but includes management in carrying out duties and establishing control and the distribution of source mainly stipulated in the constitution.

Legislative and regulatory authority is achieved in three ways: 1) attribution, 2) delegation, and 3) mandate. Legislators provide government authority to government organs through attribution, delegation, and mandate. Mandate happens when a government organ enables its jurisdiction to be exercised on its behalf by another organ. To put it simply, attribution authority refers to the management of government administrative bodies or officials derived directly from laws and regulations. In contrast, delegation authority refers to the control of administrative bodies/officials derived from the delegation of other administrative bodies/officials, with juridical responsibility transferred to the recipient of the delegation. The mandate is not a transfer of authority but rather the exercise of power by the ranks of government administration in the absence of the decisive official.

The 1945 Constitution vests the State Audit Board the jurisdiction to perform audits of the administration and accountability of state finances. Additionally, the 1945 Constitution provides tighter regulation of public finances and the Supreme Audit Agency in the law. The State Finance Law No. 17 of 2003 regulates state finances. State finances encompass all of the state's monetary-valued rights and duties and all property in the form of money or goods that can be utilized as state property in connection with the exercise of these rights and obligations. State finances include but are not limited to the state's authority to collect taxes, issue and circulate currency, state revenues, state expenditures, and state assets handled by the state or by third parties, including purchases independent from state enterprises.

Experts argue that state finances include the State Revenue and Expenditure Budget plus an analysis of Article 23, which explains that the State Revenue and Expenditure Budget is only an element of state finances. After the amendment to the 
1945 Constitution, state finances have expanded and are not only state budgets and revenues but include state-owned money contained in or controlled by any legal subject of civil entities or individuals, as long as it is money or assets that belong to the state.

In examining state finances, the State Audit Board examines three types of audits, namely: 1) Financial Audit, which is an examination of financial statements that aims to provide adequate assurance whether a financial report has been adequately presented or not; 2) Performance Examination, namely examination of state finances which consists of an examination of economic and efficiency aspects as well as an examination of effectiveness aspects; and 3) Examination with a specific purpose, namely an examination that aims to provide a conclusion on a matter being examined, this examination can be an examination, review, or agreed procedure. Each examination begins with the determination of the purpose and the type of examination to be carried out.

The State Audit Board, in carrying out its duties, examines the management and responsibility of state finances according to Law number 15 of 2006 concerning the State Audit Board; in the article, it is explained that there are three stages, namely Planning, Auditing, Audit Implementation and Audit Reporting. The audit process carried out by the Supreme Audit Agency is based on the Decree of the Supreme Audit Agency of the Republic of Indonesia Number 5/K/I-XIII.2/10/2015 concerning Guidelines for the Audit Management of the Supreme Audit Agency, from now on referred to as PMP, which can be explained as follows:

a. In the first stage, namely Audit Planning. This stage is the initial step of the audit after considering the audit policies and strategies used and the audit management risks of the Supreme Audit Agency as the basis for determining the objectives, scope, and resources needed in an audit process. Audit planning is required to carry out audit planning efficiently, effectively and following audit policies, audit activity plans, and audit standards set by the State Audit Board. This process provides an output, namely the Examination Program and Assignment Letter. The mechanism for planning the inspection is described in the following figure: 


\section{Formation of Audit Planning Team}

The formation of this team is the first step in audit planning which has the aim of developing an Audit Program.

\section{Preparation of the Examination Program Package}

Understanding of the object, and the inspection program, and the preparation of the inspection program and approval of the assignment.

\section{Preparation of Individual Work Programs}

The team leader distributes tasks to each member for the inspection steps contained in the Examination Program

\section{Examination Support Management}

Issuance of Official Travel Letter, disbursement of examination fees. accommodation arrangements, as well as transportation during the inspection.

\section{Figure 1. Inspection Planning Mechanism}

Source: Data Proceed

b. Audit implementation is the realization of audit planning so that the audit can be carried out efficiently, effectively, and following the audit standards set by the State Audit Board. The audit implementation process produces Audit Working Papers, Audit Findings, and Final Audit Implementation Reports. The implementation of the inspection is divided into two activities, namely the inspection activity and the termination of the examination. Inspection activities are activities that are carried out when the Examination Team is in the field. Inspection activities start from the initial communication and last contact with the inspected entity's officers. The inspection planning mechanism is presented in the following figure: 


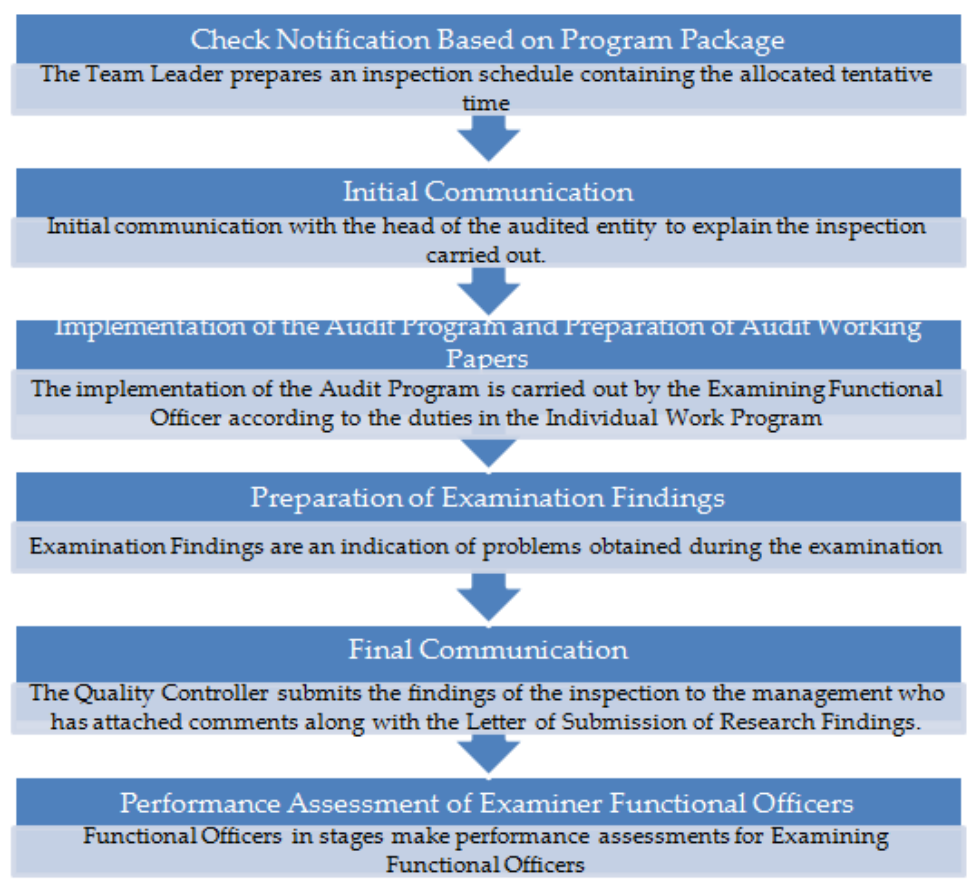

\section{Figure 2. Mechanism of Inspection}

Source: Data Proceed

c. Audit Reporting: Audit reporting is preparing reports based on audit findings obtained during the audit. The reporting process is organized by the Examining Functional Officer, Structural Officer, and Audit Task Provider following their respective authorities. The results of this reporting process are the Examination Results Report and Semester Examination Results Summary. The Audit Reporting Mechanism is presented in the following figure:

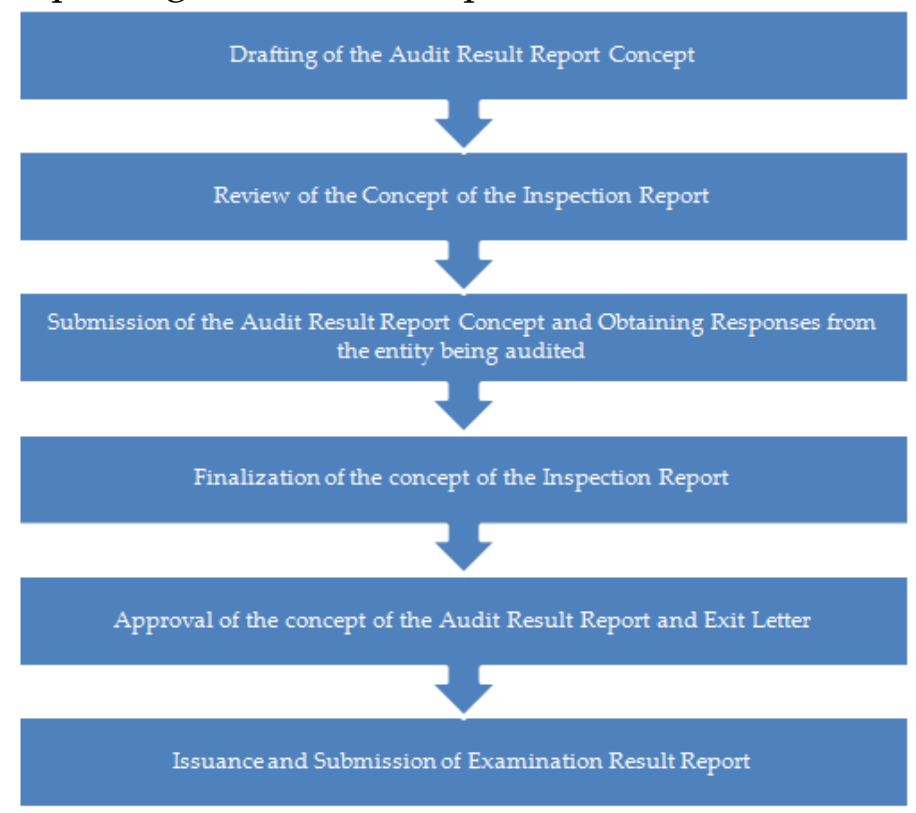

Figure 3. Inspection Reporting Mechanism

Source: Data Proceed

As a high-ranking institution in charge of examining the management and responsibility of state finances, the Supreme Audit Agency has implemented 
transparency and accountability practices, especially in reviewing the control and responsibility of state finances by the central government in 2019 to realize excellent and clean/governance.

The Supreme Audit Agency of the Republic of Indonesia has carried out its duties in examining the management and responsibilities of state finances in 2018, where the audit results are summarized in the Semester Examination Results Summary (IHPS) 1 2020. The Semester Examination Results Summary compilation to comply with the provisions of Article 18 of Law Number 15 of 2004 concerning Audit of State Finance Management and Accountability.

\section{State Audit Standards}

The implementation of audits based on auditing standards is expected to increase the credibility of the information reported or obtained from the audited entity through the collection and examination of objective evidence. In its application, this State Financial Audit Standard applies to all audits carried out on entities, programs, activities and functions related to the implementation of state financial management and responsibility. The State Financial Audit Standards are divided into several aspects, which are described in the following table:

Table 1. State Audit Standards

\begin{tabular}{|c|c|}
\hline Standard & Explanation \\
\hline General Standard & $\begin{array}{l}\text { This standard relates to ethics, independence, integrity, } \\
\text { professionalism, quality control, competence, } \\
\text { consideration of non-compliance, inspection } \\
\text { communication, and audit documentation in the } \\
\text { implementation and reporting of audit results, } \\
\text { relationships with professional standards used by } \\
\text { public accountants, as well as the obligations of } \\
\text { Government Internal Supervisory Apparatus and public } \\
\text { accountant in the audit of state finances. }\end{array}$ \\
\hline $\begin{array}{l}\text { Inspection } \\
\text { Implementation } \\
\text { Standard }\end{array}$ & $\begin{array}{l}\text { Regulates the auditor's responsibilities which include } \\
\text { planning, collecting audit evidence, developing } \\
\text { findings, and supervising. }\end{array}$ \\
\hline $\begin{array}{c}\text { Inspection Reporting } \\
\text { Standard }\end{array}$ & $\begin{array}{l}\text { Regulate the auditor's obligations in preparing the } \\
\text { Audit Result Report for financial, performance, and } \\
\text { audits with specific objectives. The Audit Result Report } \\
\text { serves to communicate the results of the examination to } \\
\text { the competent authorities based on the applicable laws } \\
\text { and regulations, to avoid misunderstanding of the } \\
\text { results of the investigation, to make the results of the } \\
\text { examination as material for corrective action by the } \\
\text { responsible party and to facilitate follow-up monitoring. }\end{array}$ \\
\hline
\end{tabular}

Source: Data Proceed 
The State Financial Auditing Standard aims to provide an audit of financial management and accountability that can be accounted for. Because the results of the examination by the Supreme Audit Agency will be used as the basis for supervision for the executive and legislative branches, therefore, the results of the investigation should not only be to satisfy one party at the expense of the interests of the state, which results in unlawful acts.

The follow-up to examining the Financial Statements that the Supreme Audit Agency has carried out is then submitted to the Regional House of Representatives no later than two months after receiving the financial report from the central/regional government. The Audit Result Report is also submitted to the President/Governor/regent/mayor following their respective authorities. This also applies equally to performance audits and audits with a specific purpose conducted by the Supreme Audit Agency. After the State Audit Board submits the Audit Result Report, if there is a recommendation, it becomes the domain of the government inspectorate to follow up on the Audit Result Report or implement the proposal.

The Supreme Audit Agency submits the audit results to the head of the institution that is responsible for ensuring the implementation of the follow-up to the recommendations on the results of the audit. The Audit Result Report must be followed up in the form of an explanation or answer by the authorized official to the State Audit Board regarding the follow-up to the recommendations in the audit result report. And the follow-up must be submitted to the State Audit Board no later than 60 (sixty) days after the information on the audit results is received.

Suppose the follow-up on the recommendations cannot be carried out within the stipulated period. In that case, the official is obliged to provide a valid reason why the follow-up action is not being fulfilled. Legitimate grounds do not simply absolve the Officer from following up on the recommendation on the examination results. Suppose further steps are not following the guidance and have not been followed up until the specified time limit. In that case, the State Audit Board may conduct discussions with the Officials with the members of the Supreme Audit Agency and Main Auditor/Head of Representatives with the Officials and locate in the offices of the State Audit Board.

\section{CONCLUSION}

Based on the study and analysis of legal sources, it can be concluded that: 1) The position of the Supreme Audit Agency of the Republic of Indonesia in the state administration system is a state institution whose authority is granted by the 1945 Constitution of the Republic of Indonesia (constitutionally entrusted power) so that it can be called the main state organ or the primary state agency, and 2) The Supreme Audit Agency has the authority to carry out audits of state and regional financial management. The State Audit Board is authorized to audit the State Revenue and Expenditure Budget for the national scope. The financial audit results contain a statement of opinion about the fairness of the information presented in the government's financial statements. All regional governments must submit financial 
reports to the State Audit Board no later than three months after the end of the fiscal year as mandated in Article 23E of the 1945 Constitution of the Republic of Indonesia and Law Number 15 of 2006 concerning the State Audit Board.

\section{REFERENCES}

1. Adrison, V. (2019). The Audit Board of Republic of Indonesia's Opinon and Bribery in Local Governments in Indonesia. Jurnal Tata Kelola \& Akuntabilitas Keuangan Negara.

2. Aminah, Lindrianasari, \& Rosmiaty. (2016). Good government governance and opinions of the audit board of Republik Indonesia. International Journal of Monetary Economics and Finance, 9(2), 198-211.

3. Astuti, Y. D., \& Adrison, V. (2019). The Audit Board of Republic of Indonesia Opinion and Bribery in Local Governments in Indonesia. Jurnal Tata Kelola dan Akuntabilitas Keuangan Negara, 5(2), 125-138.

4. Aswar, K. (2019). Financial performance of local governments in Indonesia. European Journal of Business and Management Research, 4(6).

5. Bintari, A. E. (2017). Rights of Police Action by the Financial Audit Board of the Republic of Indonesia. JILL, 2, 3.

6. Dharma, D. P. B., Sandhyaduhita, P. I., Pinem, A. A., \& Hidayanto, A. N. (2017). Antecedents of intention-to-use of the e-audit system: a Case of the Audit Board of the Republic of Indonesia. International Journal of Business Information Systems, 26(2), 185-204.

7. Hasiara, L. O., \& Padliansyah, R. (2017). Analysis of Giving Opinion of the Audit Board of the Republic of Indonesia (BPK) on Unqualified Opinion (WTP). Journal of Finance and Accounting, 5(6), 206.

8. Idrus, Y. A., Achsani, N. A., \& Hardiyanto, A. T. (2018). The Relationship between the Audit Board of the Republic of Indonesiaâ€ $€^{\mathrm{TM}} \mathrm{s}$ (Bpk) Opinion with Regional Government Financial Report and Corruption. Jurnal Tata Kelola dan Akuntabilitas Keuangan Negara, 4(1), 23-39.

9. Julianti, Y., \& Pamungkas, B. (2019, July). Design a Risk-Based Review Program for the Audit of Governments Financial Statements Conducted by the Public Accountant for The Comptroller of the Supreme Audit Board of the Republic of Indonesia. In Asia Pacific Business and Economics Conference (APBEC 2018) (pp. 4956). Atlantis Press.

10. Komalasari, N. (2016). Does the rotation of the head of the audit office across offices impact audit quality? Study case of the Audit Board of the Republic of Indonesia. Jurnal Tata Kelola dan Akuntabilitas Keuangan Negara, 2(2), 137-150.

11. Kusumawati, A., \& Syamsuddin, S. (2018). The effect of auditor quality on professional scepticism and its relationship to audit quality. International Journal of Law and Management.

12. Kusumo, K. (2018). Kusumo, BYA, Koeswoyo, PS, \& Handoyo, S."Analyze the Effect of workplace spirituality on Auditor Dysfunctional Behavior and its 
Implication to Audit Quality: Study at the Audit Board of the Republic of Indonesia. Journal of Accounting Auditing and Business, 19-33.

13. Probohudono, A. N., Hartanto, R., \& Putra, R. P. (2018). Determinants of settlement audit recommendation of the audit board of the Republic of Indonesia. International Journal of Public Sector Performance Management, 4(2), 169189.

14. Probohudono, A. N., Hartanto, R., \& Putra, R. P. (2018). Determinants of settlement audit recommendation of the audit board of the Republic of Indonesia. International Journal of Public Sector Performance Management, 4(2), 169189.

15. Ruliana, T., Indrawati, A., \& Febrina Lubis, S. (2017). Audit electronic (e-Audit) to the financial statements. Scientific Papers: Management, Economic Engineering in Agriculture \& Rural Development, 17(3).

16. Setiyawati, H. (2016). Effect of weaknesses of the internal control systems and non-compliance with statutory provisions on the audit opinion of the audit board of the Republic of Indonesia. Journal of Engineering Research and Application ISSN, 2248-9622.

17. Setyaningrum, D., Gani, L., Martani, D., \& Kuntadi, C. (2015). The effect of auditor quality on the follow-up of audit recommendation. International Research Journal of Business Studies, 6(2).

18. Suwanda, D. (2015). Factors affecting the quality of local government financial statements to get unqualified opinion (WTP) of audit board of the Republic of Indonesia (BPK). Research Journal of Finance and Accounting, 6(4), 139-157.

19. Syarfina, A., \& Heru, T. (2019). The role of emotional quotient to moderate effect of role stress on examiner job performance in Audit Board of the Republic of Indonesia. Russian Journal of Agricultural and Socio-Economic Sciences, 86(2).

20. Zulkarnain, P. D. (2014). Institutional strength and strategic use of e-government to improve government collaboration: A study on the implementation of e-audit in Audit Board of The Republic of Indonesia. In The Asian Conference on Society, Education and Technology (pp. 21-36). 